Estudios sobre el Mensaje Periodístico

ISSN-e: 1988-2696

http://dx.doi.org/10.5209/ESMP.55590

\title{
Efecto inmersión y relevancia cognoscitiva en los vídeos de guerra en la Red
}

\author{
Fernando Redondo Neira ${ }^{1}$
}

Recibido: 31 de mayo de 2016 / Aceptado: 10 de noviembre de 2016

Resumen. La manera de representar la guerra y los conflictos sociales han ido cambiando a medida que aquellos han ido cambiando también: las últimas guerras de Irak o de Afganistán, las primaveras árabes, las actuaciones del Estado Islámico...Las imágenes amateur difundidas por Internet están sustituyendo a los relatos periodísticos profesionales. En su condición de fragmentos aparentemente inconexos, conforman un mosaico visual caracterizado por la inmediatez, la crudeza y lo escasamente elaborado. Se imponen por la acentuada sensación de realismo que logran transmitir y por la mirada subjetiva por la cual consiguen trasladar al espectador al escenario de los hechos. En definitiva, nuestro objetivo será comprobar el grado de conocimiento que cabe adquirir respecto de los conflictos abordados a partir del análisis de esta muestra de registros audiovisuales situados en la red.

Palabras clave: Internet; guerra; crudeza; realismo; conocimiento.

\section{[en] Immersion effect and cognitive relevance in war videos on the Web}

\begin{abstract}
The way to represent war and social conflicts have been changing as those have been changing too: the recent wars in Iraq and Afghanistan, the Arab Springs, the actions of the Islamic State. The webcast amateur images are replacing the professional journalistic stories. As seemingly unrelated fragments, they form a visual mosaic characterized by immediacy, rawness and poorly development. They are imposed thanks to the heightened sense of realism that manage to convey and the subjective view whereby the viewer is transported to the scene of action. In brief, our goal will be to check the degree of knowledge that should be acquired regarding conflicts through the analysis of this videos located on the internet.
\end{abstract}

Keywords: Internet; war; crudeness; realism; knowledge.

Sumario. 1.Introducción. 2. Métodos para analizar un mosaico de imágenes. 3. Análisis I. Vídeos de guerra: la mirada, el movimiento, la continuidad. 4. Análisis II. Exceso de realidad. 5. Análisis III. La atracción del horror. 6. Conclusión. Experiencia mediada y conocimiento. 7. Referencias bibliográficas.

Cómo citar: Redondo Neira, Fernando (2017): "Efecto inmersión y relevancia cognoscitiva en los vídeos de guerra en la Red”, en Estudios sobre el Mensaje Periodistico 23 (1), 179-190.

\section{Introducción}

La hoy casi olvidada crisis argentina de 2002 fue recreada, contextualizada y explicada a través de un documental de marcado carácter militante y didáctico, $\mathrm{Me}$ -

$1 \quad$ Universidad de Santiago de Compostela.
E-mail: fernando.redondo@usc.es 
moria del saqueo (Fernando "Pino" Solanas, 2003). Lo singular de este filme, radica, para lo que a nosotros nos interesa, en haber utilizado fragmentos de grabaciones amateurs, vídeos registrados por los propios participantes en huelgas y manifestaciones que habían sido difundidos previamente a través de Internet y que habían constituido una herramienta más para la toma de conciencia y la expresión del descontento social. También un filme como Redacted (Brian de Palma, 2007) ejemplificaba cómo ciertas ficciones recurrían a la particular estética de estos vídeos como modelo para sus propias propuestas. Son sólo dos muestras de la colonización llevada a cabo sobre el cine profesional por parte de lo que bien podría denominarse "estética Youtube", sobre todo en el caso de Redacted. Supone, también, en cierto modo, otorgar carta de naturaleza a un nuevo modo de abordar la representación audiovisual de la guerra o de los conflictos sociales, con lo que ello conlleva de un nuevo acceso a dichos conflictos, una nueva mirada y un tipo de conocimiento diferente.

Desde la ya lejana crisis argentina hasta las últimas imágenes que pueblan la red sobre las actuaciones del Estado Islámico, Internet ha ido acumulando vídeos de los más diversos conflictos en su más amplia pluralidad de formas: altercados, rebeliones, guerras...Conforman un corpus de imágenes inabarcable, caótico, fragmentado, inconexo y desorganizado; ajeno a los postulados de jerarquía y contextualización que deberían regir un relato audiovisual de carácter periodístico. Lo que ofrecen estas piezas audiovisuales, por el contrario, es una fuerte sensación de inmediatez, de acceso directo a los hechos, de crudeza y escasa (o nula) elaboración. Tratándose de aspectos comunes a todas estas producciones, habrá que partir de la obviedad de que conviene diferenciar entre un vídeo registrado en una manifestación por los propios participantes de aquel que muestra una ejecución a cargo de un grupo terrorista. No nos ocuparemos de éstos últimos, pues es notoria su intención de servir a la propaganda del horror. Además, tal y como ya han establecido diversos especialistas, son imágenes que niegan la reflexión y que no generan el análisis, sino la indiferencia (Marzano, 2010:100). Estaríamos, por tanto, en estos casos, ante lo que algunos autores han calificado de "estadio improductivo de la imagen", ante un cierto colapso de la representación, que ya no cumpliría la función de mediación y de la que sólo cabría esperar invisibilidad e indiferencia (Cruz, 2005:157). Añadamos aquí las siempre lúcidas reflexiones de Susan Sontag, quien se pregunta si es posible la indignación en un contexto de sobreabundancia de este tipo de vídeos, que más bien parecen filmes de ficción o videojuegos. La ensayista norteamericana afirma, a su vez, que únicamente tienen derecho a contemplar este tipo de imágenes quienes pueden hacer algo para aliviar o solucionar las situaciones que éstas muestran. Los demás sólo somos voyeurs (Sontag, 2003:49). La atracción visual parece ocupar entonces el lugar del pensamiento lógico y en ella todo se agota en un mirar inútil y fascinado.

\section{Métodos para analizar un mosaico de imágenes}

Teniendo presente todo lo anterior, de la ingente variedad de piezas audiovisuales disponibles en diversas plataformas web, nuestra atención se dirigirá, por tanto, a un tipo muy específico de vídeos, aquellos que recogen una acción concreta en un momento del combate, una acción grabada por los propios participantes en dicha ac- 
ción o, en todo caso, por un observador cercano o implicado en ella de algún modo, no tratándose de un operador de cámara profesional que trabajara para un medio de comunicación, aun siendo un free-lance.

Del amplio muestrario de guerras y conflictos de los que la web puede dejar constancia visual, probablemente la reciente intervención norteamericana en Afganistán y en Irak sirva mejor que ningún otro ejemplo a los intereses de nuestro estudio. El análisis a que sometamos aquí una muestra representativa de piezas extraídas de aquellos sucesos se orientará por dos principios básicos, de entre los propuestos por autores como Aumont y Marie: la fidelidad empírica, mediante afirmaciones avaladas por datos extraídos de las propias creaciones analizadas, y la relevancia cognoscitiva, la cual, yendo más allá de la evidencia, buscará alcanzar un conocimiento nuevo de los hechos mostrados (Aumont y Marie, 1990: 59). Completará nuestro acercamiento la atención prestada a las reflexiones de aquellos pensadores o estudiosos que, según nuestro criterio, se han propuesto explicar cuestiones tales como visión y violencia o las imágenes y el exceso, entre algunas otras ya muy estudiadas.

En otro orden de cosas, cabe recordar que nos proponemos analizar piezas audiovisuales de relativa corta duración, acompañadas de un título meramente informativo u orientativo y, que, en ocasiones, incluye, a través de su visionado en la web, los correspondientes comentarios de los internautas que, ciertamente, pueden conducir hacia nuevos ámbitos semánticos. Con todo, aquí nos ocuparemos únicamente del texto audiovisual, obviando así otras lecturas que se han ido incorporando y que, como reflejo de una reflexión de urgencia y poco elaborada, apenas pueden ahondar en la creación de significados. Por otro lado, es ya una práctica habitual que los informativos de televisión se apropien de estas imágenes, las reciclen e introduzcan en sus propios vídeos para conformar una suerte de mosaico visual del que participan otros contenidos de naturaleza y procedencia diversa. Lo que nosotros buscamos, por el contrario, es el material original, el material sin editar o, en la medida de lo posible, con un escaso grado de intervención, lo cual no siempre es fácil de comprobar sin otro procedimiento que la simple navegación a través de la red.

Otra consideración previa a todo análisis de este tipo de vídeos debe resaltar el hecho de que nos encontramos ante una actividad amateur, que no responde necesariamente a los estándares profesionales de captación de imágenes, que no se rige, entonces, por criterios estrictamente periodísticos. Su relevancia informativa, no obstante, está fuera de toda duda en muchos casos, como así han consensuado ya numerosos especialistas. Las restricciones impuestas a los reporteros a la hora de trabajar en zonas de conflicto, así como la mayor disponibilidad de dispositivos de grabación por parte de quienes participan directamente en dichos conflictos, y que los avances tecnológicos permiten, hacen posible esta situación relativamente nueva. Las grabaciones a cargo de aficionados que captan los hechos desde el interior de los mismos y que luego alimentarán los informativos de televisión es una práctica ya totalmente asentada. Los acontecimientos del $11 \mathrm{~S}$ supusieron aquí un punto de inflexión. Para Andrew Hoskins, el registro televisivo de aquellos hechos dependió, en buena medida, de las cámaras que tenían los residentes en el centro de Nueva York. Añade este autor que una parte importante de la historización de la catástrofe se ha construido a partir de la fusión de lo público con lo privado, de lo profesional con lo amateur (Hoskins, 2004:19). 


\section{Análisis I. Vídeos de guerra: la mirada, el movimiento, la continuidad}

En lo que va de 2003 a 2013, entre la guerra de Irak y el aún vigente conflicto en Siria, no ha dejado de aumentar, por supuesto, el material audiovisual que circula por la red. En ocasiones, algunos de estos vídeos acaban desapareciendo, después de meses o años, de las plataformas más visitadas, como la global y omnipresente YouTube. Otras veces, figuran con rótulos de advertencia acerca de lo turbador que puede llegar a ser su contenido y justificaciones sobre su interés documental o informativo. Se trate bien de escenas de combate de los bien equipados y organizados soldados americanos en un caso, o bien de los más precarios y caóticos rebeldes sirios, todos estos vídeos comparten un rasgo primordial en el que basan su atractivo: el efecto de inmersión que supone ese radical tratamiento enunciativo que impone la cámara subjetiva, una mirada situada en el interior de la escena mostrada, que describe y cuenta desde dentro, que sitúa al espectador en el escenario de los acontecimientos y le hace partícipe, en definitiva, de una experiencia extrema, la experiencia del combate. Todo ello a pesar de que el visionado continuado de estas piezas audiovisuales puede provocar otro efecto que, en cierto modo, se opone al anterior. Nos referimos al tedio que genera la reiteración de los motivos visuales, escenas, acciones o ademanes, como el intercambio de disparos, las explosiones, las carreras nerviosas, los gritos y las imprecaciones. Y sobre todo, la muy abundante presencia de tiempos muertos en los que no cabe más que esperar a que algo ocurra, cualquier cosa que agite la calma tensa de un plano secuencia que, necesariamente, lo mostrará todo desde un único punto de vista, ese único emplazamiento de quien porta la cámara y que, antes que el vértigo del combate, lo que transmite, la mayoría de las veces, es una sensación de nerviosismo y espera. Lo que aquí se muestran, efectivamente, son acciones frenéticas, agitadas por el dinamismo, la tensión y la urgencia, pero también abundantes momentos de una aburrida espera que forma parte, tanto o más que la lucha, de la experiencia de la guerra. Una lectura atenta de estas imágenes permite acceder a esta otra verdad que emerge de todo conflicto bélico, como supo ver Vicente J. Benet: "Las imágenes más actuales de la guerra se construyen desde miradas múltiples e incontroladas en las que el horror permanece agazapado tras lo que parece anodino e irrelevante" (Benet, 2007: 53)

La escasa o nula fragmentación de los planos traslada al espectador la idea de una continuidad espacio-temporal, de un mayor respeto por la duración real y el desarrollo natural de las acciones, lo que posibilita, atendiendo al principio baziniano relativo a la ambigüedad de lo real, que los propios hechos se expresen por sí mismos. Se genera entonces una paradójica sensación de tiempo extendido que se origina también en la expectación creada por la demora en la resolución de los hechos. En última instancia, se activa aquí un mirar fascinado en forma de deseo visual, una ansiedad escópica que, sobre todo en las escenas de acción, tanto se parece a la generada por los videojuegos del género bélico.

Del volumen ingente de material disponible, podemos realizar un primer intento de establecer una cierta categorización que bien puede basarse en lo citado acerca de la particular mirada inscrita en estos registros visuales. Algo tan elemental como que no hay imagen posible sin un punto de observación, un lugar físico que en el contexto de la escritura audiovisual supone también una dimensión cognitiva y un posicionamiento moral. Se tratará, por lo tanto, en unos casos, de una ubicación fija, que se corresponde, así, con una posición de combate, con la mirada de quien actúa desde una específica posición y sin otro movimiento posible que leves reencuadres 
sobre un plano fijo, o bien movimientos de aproximación con el zoom como acercamiento visual a la posición del enemigo, casi siempre para comprobar el efecto de un obús o de una ráfaga de disparos, o bien el movimiento que sigue a la detonación y a la nube de polvo que se levanta. Otras veces, aun manteniendo un punto de observación fijo, asistimos a un movimiento constante en panorámica a derecha o a izquierda, siempre a la busca del elemento visual de mayor relevancia, en una manifestación nueva de esa mirada ansiosa que se dirige siempre hacia el lugar de la acción. Dichos movimientos no responden a otro criterio que el de buscar una acción que mostrar. Son movimientos vacilantes, perdidos a veces en la exploración del espacio que difícilmente logran captar con nitidez, apenas una serie desordenada de panorámicas y zooms que, en un ir y venir vacilante, se corresponden sin duda con la confusión propia de toda acción de combate, que, en el plano sonoro, se completa con los disparos, los gritos, alaridos y exclamaciones ${ }^{2}$. En definitiva, no son sino variaciones en torno al asunto capital de punto de vista, un concepto de amplia y rica variedad de significados que incluye, en primer lugar, aspectos técnicos como ubicación y angulación de la cámara y que determina, además, quién mira y desde dónde con la intención de ver o de mostrar qué y a quién. En un nivel de mayor conceptualidad, el punto de vista se ocupa también de gestionar la noción de distancia en lo que ésta representa entre la implicación emocional y la seguridad que proporciona la mediación de la pantalla. Se produce, entonces, la singular paradoja de, por un lado, entender la pantalla como frontera que separa el espacio del relato del espacio de la recepción, mientras asistimos al simulacro que finge precisamente la ausencia de dicha distancia, buscando así olvidar la existencia de esta frontera.

La participación del movimiento alcanza una nueva dimensión si aquel punto de observación se constituye en punto móvil que organiza la imagen desde la aportación básica del travelling. La mirada que se haga cargo de dicho travelling será ya una mirada absolutamente implicada en el fragmento de lo real mostrado y que traslada visualmente a un espectador con el que necesariamente se identifica en virtud del recurso al dispositivo enunciativo propio de la cámara subjetiva. Se suceden entonces los movimientos bruscos, los consabidos tirones de cámara, los descuidados planos de suelo de quien sale corriendo o se ha caído. El sujeto-espectador se siente de nuevo inmerso en la confusión de la lucha y en el intercambio de disparos, participa de las carreras de quien busca ocupar posiciones estratégicas de combate. Todo muy distinto, de este modo, de la elaborada coreografía que organiza un bien medido montaje del cine de ficción del género bélico más asentado, mientras que otros filmes contemporáneos, como el ya citado Redacted, sí organizan su discurso a partir de los recursos estilísticos que presentan estos vídeos.

Un análisis más detenido de estas piezas audiovisuales podría abordar aspectos muy diversos de las formas de representación de los conflictos contemporáneos. Siempre desde el estudio del punto de vista y del binomio distanciamiento / implicación, podemos detenernos aquí en cómo muchos de estos vídeos interpelan al espectador en todo aquello que tiene que ver con sentimientos como la insensibilidad, la indiferencia o la crueldad, que sin duda afloran en todo conflicto bélico tal y como estos registros visuales se ocupan de dejar testimonio. En una búsqueda aleatoria sobre este magma casi inabarcable de piezas audiovisuales, encontramos un buen

Véase http://www.liveleak.com/view?i=f0a_1239218826, con el título U.S \& Iraqi Soldiers Engage Al-Qaeda in Baqubah (Summer 06) [Consulta: 25 de mayo de 2016] 
ejemplo de ello. Se trata de un plano secuencia de algo más de un minuto, un travelling que construye la cámara situada sobre un vehículo en marcha, con una botella de agua situada en primer término que porta un soldado. Corriendo tras el vehículo, un grupo de niños gritan e imploran que les lancen la botella. Se escuchan las risas, mofas y gritos de los soldados, cuyos rostros no vemos. Cuando finalmente dejan caer la botella, los niños pugnan entre ellos para quedársela ${ }^{3}$.

Vídeos como éste demuestran que no es preciso alcanzar ciertos límites de crueldad visual ni hacer ostentación de violencia explícita para conformar una representación veraz de la realidad de la guerra. Sin mostrar aquí tampoco escena alguna de una acción militar, es suficiente con prestar atención a la cotidianidad que se respira en un escenario de conflicto a través de una determinada puesta en escena de los sujetos implicados. La presentación de los dos grupos humanos, soldados (a quienes no llegamos apenas a ver) y niños, ocupantes y ocupados, en flagrante situación de dominio de los primeros sobre los segundos, de los más poderosos sobre los más débiles. En su sencillez, con el consabido plano secuencia, el travelling y la cámara subjetiva, el vídeo es una elocuente representación del poder que ejercen las fuerzas de ocupación sobre los ciudadanos indefensos, empezando por el poder de filmar. A su vez, aquella cámara subjetiva remite claramente a la configuración de un punto de vista que añade a la simple ubicación física un posicionamiento moral e ideológico, una particular manera de mostrar los hechos a partir de una mirada connotada con los atributos de la superioridad y la arrogancia. En el fondo, de ejemplos como éste puede derivarse una nueva y evidente dimensión perversa, pues esta mirada no está tan alejada de aquella propia de la imagen turística más estereotipada, la imagen de recuerdo de haber estado en un lugar exótico y haber documentado una experiencia merecedora de una recuperación futura.

Encontraremos los mismos recursos expresivos ya descritos para los vídeos de Irak en otros registros audiovisuales de otros conflictos, que responden también a una misma intención de documentar hechos y mostrar acciones desde el interior de lo mostrado. La característica textura "degradada" de la imagen, habitualmente pixelada, se presenta también en el material que encontramos en la red sobre los sucesos en Siria. Serán habituales también los planos "quemados" por el exceso de luz o, por el contrario, aquellos otros en los que reina la penumbra o la oscuridad casi absoluta. Es conocido el efecto verdad que se deriva de este particular aspecto descuidado, que se corresponde, por supuesto, con el movimiento vacilante, el nulo control del sonido o el inexistente trabajo de montaje que supone que solo en contadas ocasiones se recurra a una fragmentación de las acciones. Otra característica esencial de este tipo de vídeos es la imposibilidad de ofrecer el contraplano, una imposibilidad ontológica que la propia realidad impone y que hace que, necesariamente, todo se muestre siempre desde uno de los bandos en conflicto. Un buen ejemplo es el que ofrece un vídeo que muestra a un grupo de combatientes sirios que, atrincherados en una casa, son acosados por el enemigo, se defienden desesperadamente y se ven obligados a esconderse o a huir ${ }^{4}$. La inexistencia del contraplano, la continuidad de la acción derivada del plano secuencia y el punto de vista subjetivo que organiza la mostración de los hechos transmiten al espectador una agobiante sensación de peligro. Se produce así un efecto generado, a su vez, por un fluctuante movimiento de la imagen que, bien con bruscas panorámicas o bien con travellings que no parecen conducir a ningún lugar en concreto, se muestra

Disponible en http://www.youtube.com/watch?v=xSXokc-VSdg. [Consulta: 25 de mayo de 2016]

Disponible en https://www.youtube.com/watch?v=tQcTDd4V0ew [Consulta: 26 abril de 2015] 
incapaz de abandonar las estancias, habitaciones y pasillos recorridos una y otra vez; incapaz, finalmente, de encontrar una salida hacia el exterior y ofrecer así al espectador el alivio de haber dejado atrás una situación claustrofóbica.

Pese al uso reiterado de una serie de recursos básicos que, como los descritos, comparte este vídeo con tantos otros que muestran acciones similares, figura aquí un elemento novedoso: el autorretrato que, en el fragor de los disparos, se hace el soldado que porta la minicámara. En un momento dado, un giro en el movimiento de la imagen sitúa en primer término el espejo roto donde aquel se refleja. El azar ha querido aquí que las líneas irregulares del espejo formen una sugerente rima visual con el hilo de sangre que, partiendo de una herida en la frente, cruza el rostro de este combatiente. Si bien ya se ha destacado la intervención de una mirada focalizada sobre el fragmento de lo real mostrado desde una posición subjetiva, la repentina figurativización de la instancia enunciadora dota al conjunto audiovisual de una nueva dimensión autoconsciente y reflexiva. Esta interpelación al sujeto espectador desde el interior del discurso, y por parte de quien está a cargo de dicho discurso, supone establecer un contacto directo con el espacio heterogéneo de la recepción en el que el dispositivo audiovisual asume su propia condición de tal. En palabras de Francesco Casetti, ésta más que elocuente presencia de las huellas de la enunciación expresan "el hacerse y el verse del film" (Casetti, 1989: 67).

Ya que nuestro propósito último es indagar en torno al conocimiento que de determinados hechos nos ofrecen este tipo de vídeos, debemos precisar previamente cómo el particular discurso audiovisual que aquí hemos expuesto puede conducirnos a ese objetivo. Seguiremos para ello el recorrido marcado por André Gardies. Al describir la construcción significante a través de la intervención del dispositivo enunciativo, este autor asegura que la cámara produce un componente visual al actuar sobre el profílmico (localización), que deviene en un determinado punto de vista que adjudicamos a un narrador o a un personaje (mostración), sobre el que, finalmente, se desarrolla un flujo de saberes (focalización) (Gardies, 1993, 102). En relación con los vídeos alojados en la red que abordamos aquí, ese flujo de saberes circula en una doble y contradictoria dirección, aquella que marca el binomio transparencia / opacidad. Transparencia, por un lado, en relación con lo evidente de lo mostrado, lo reconocible y lo concreto; pero también esa opacidad de lo real en lo que tiene de espacio de lo informe, lo incierto o lo azaroso, lo desprovisto de una significación clara por carecer de una más exigente elaboración discursiva, debida, en buena medida, tanto a la ausencia de un marco contextual como de las razones y los antecedentes de los conflictos mostrados. También los medios convencionales, en lo que parece un contagio de estas prácticas, presentan ciertos déficits en su labor de mediación, como denuncia, por ejemplo, Santos Zunzunegui: "Cabe peguntarse (...) si cuando los medios contemporáneos hacen gala de darnos a ver los acontecimiento sin mediación alguna no están dejando al público desnudo ante unos acontecimientos que lo sumergen en la irresistible pulsión del hecho bruto" (Zunzunegui, 2009:11).

\section{Análisis II. Exceso de realidad}

Sobre la producción de sentido que aquí se genera, el particular acceso a determinados conflictos actuales que estos vídeos proporcionan y el grado de conocimiento que cabe adquirir a través de su visionado, consideramos que puede ser especial- 
mente útil configurar un marco de referencia del que bien pueden participar algunos nombres esenciales del pensamiento contemporáneo. En primer lugar, algunos de los ensayos y textos teóricos de Georges Didi-Huberman nos aportan un lúcido y elaborado pensamiento acerca de las relaciones que las imágenes mantienen con la realidad del conflicto, acerca de cómo se acercan a él, cómo lo muestran, cómo lo describen y cómo tratan de explicarlo. Y habrá que empezar, en este sentido, por fijar también una actitud para el espectador, si es que éste pretende, obviamente, extraer algún conocimiento nuevo de su contacto con las imágenes. Para ello, habrá que atender a lo siguiente: "Las imágenes no nos dicen nada, nos mienten o son oscuras como jeroglíficos mientras uno no se tome la molestia de leerlas, es decir de analizarlas, descomponerlas, remontarlas, interpretarlas, distanciarlas fuera de los 'clichés lingüísticos' que suscitan en tanto que 'clichés visuales"' (Didi-Huberman, 2008: 44). Y es precisamente de este modo, huyendo de los citados clichés, cómo Didi-Huberman propone la brillante metáfora de que la imagen arde en contacto con la realidad, para, a continuación, ir desgranando lo que esto significa. Y así, la imagen arde por el deseo, por la urgencia que manifiesta en aquello que expresa; por el resplandor, por la posibilidad visual abierta en su misma consumación; por su intempestivo movimiento, la incapacidad de detenerse una vez puesta en marcha; por su audacia, la imposibilidad de volverse atrás una vez iniciado su camino; por el dolor, el que procura a quien se toma el tiempo suficiente para que le importe, con lo que esto supone, añadimos nosotros, en el caso de vídeos de guerra; por la memoria, porque todavía arde cuando ya no es más que ceniza (Didi-Huberman, 2013: 35).

Precisamente, conviene detenerse aquí, siquiera mínimamente, en lo que este autor tiene que decir sobre las relaciones imágenes / memoria. Y para ello, habrá que acudir a uno de sus libros más célebres. En Imágenes pese a todo, cuando se pregunta si lo ocurrido en Auschwitz entraría dentro de la categoría de lo pensable o de lo decible (que sí entraría porque sí se pensó y sí ocurrió), defiende la utilidad de las pocas y precarias fotografías tomadas en el interior de los campos porque, afirma, "La imagen surge donde el pensamiento se detiene" (2004, p. 56). Concluye nuestro autor con la idea de que si el horror de los campos desafía a la imaginación, entonces más necesarias se harán cada una de las imágenes arrebatadas a esa experiencia. Si la reflexión, añade, se hace imposible es donde la memoria se hace necesaria (2004, p 77) ¿Y dónde reside la memoria? Las imágenes son un buen lugar para contenerla $\mathrm{y}$, en este sentido, señala Didi-Huberman, pueden ser un eficaz antídoto frente a los sufrimientos del futuro.

Ya que hemos invocado el efecto de transparencia como ausencia de una mediación que incluiría las necesarias dosis de distancia y reflexión, Jean Baudrillard, por su parte, alude al exceso de realidad que anula la posibilidad de una representación eficaz. Afirma el autor de El crimen perfecto que cada avance en la información, cada adelanto tecnológico, nos acerca más a una transparencia ineluctable, que la cultura de la información se hunde bajo un exceso de información; que la realidad, en definitiva, parece desaparecer bajo el peso de su representación, desprovista ésta de todo atisbo de ilusión, entendida aquí como carencia e imperfección, como ese espacio en blanco reservado a nuestra capacidad de pensar y como vía abierta, por tanto, a una cierta posibilidad de acceder a algún tipo de conocimiento. Si dicha ilusión se presenta completa en sí misma, asumir y pensar la realidad ya no parece posible. Lo virtual, señala Baudrillard, es el mejor ejemplo de todo ello: "En el mundo real, la muerte también se vuelve real, y segrega un pavor desproporcionado. Mientras 
que en un mundo virtual nos ahorramos el nacimiento y la muerte, a la vez que una responsabilidad tan difusa y abrumadora que es imposible de asumir" (Baudrillard, 1996: 57). El visionado de estos vídeos de la red producen una sensación semejante, la de participar en realidades atroces desde la distancia de las pantallas, desde un lugar a resguardo de la crueldad y la violencia. La transparencia "ineluctable" también dificulta la emergencia de alguna forma de empatía para con los sucesos mostrados y los individuos que los sufren. En definitiva, sobre el acceso a las realidades atroces de la guerra y a la experiencia extrema que aquella representa, y que los avances tecnológicos permiten sin escamotearnos ni el horror ni el tedio, consideramos que puede ser útil el pensamiento de Baudrillard que, expresado con su particular y estimulante radicalidad, incide en la idea de una saturación de lo real que niega al sujeto la posibilidad de un conocimiento reflexivo: "Vivimos en la ilusión de que lo real es lo que más falta, cuando ocurre lo contrario: la realidad ha llegado a su colmo. A fuerza de proezas técnicas, hemos llegado a tal grado de realidad y de objetividad que podemos hablar incluso de un exceso de realidad que nos deja mucho más ansiosos y desconcertados que el defecto de realidad, que por lo menos podíamos compensar con la utopía y lo imaginario, mientras que para el exceso de realidad no existe compensación ni alternativa" (Baudrillard, 1996: 91).

También Gilles Lipovestsky y Jean Serroy basan sus reflexiones en un pensamiento del exceso, de la hipervisualidad y la hiperpresencia. Para ambos autores, nuestra relación con el mundo y con los demás pasa de manera creciente por una red de pantallas, todos somos grabados y podemos grabar: "Filmar, enfocar, visionar, registrar los momentos de la vida: todos estamos a un paso de ser directores y actores de cine, casi a un nivel profesional" (Lypovetsky y Serroy, 2009: 25). De ello también participan, desde luego, los soldados estadounidenses desplazados en Irak o los combatientes en el conflicto sirio, y de paso invitan al espectador (al internauta, donde sea que se haya conectado) a vivir por delegación la experiencia de la guerra. A esto Lipovetsky y Serroy lo han llamado cinematografización del mundo. Hablamos de la creación de un universo paralelo habitado por lo banal y lo efímero, lo cotidiano y lo íntimo; pero también los autores de actos violentos se graban a sí mismos, como se graba lo atroz de la guerra o la crueldad ejercida sobre los más débiles. Los vídeos de Irak y los de Siria recogen, ciertamente, como hemos adelantado, momentos banales y de una cotidianidad anodina, ese sopor derivado del uso del plano secuencia que, pues no desdeña los tiempos muertos, ignora las elipsis propias de todo relato canónico. Pero, en otras ocasiones, tanto el movimiento frenético de la cámara que busca captar, sin conseguirlo, todos los detalles de la acción, como el punto de vista subjetivo que nos sumerge en el fragor de la batalla, responden al deseo de un público ávido de sensaciones, novedades y experiencias impactantes. Entraríamos entonces en el terreno del hipercine, en palabras de Lipovetsky y Serroy, el cual "refleja una demanda general de sensaciones y emociones perpetuamente renovadas" (Lypovetsky y Serroy, 2009: 80).

Lo que para los autores antes citados es cinematografización del mundo, para Paul Virilio es pancinema permanente, nuestros actos más corrientes convertidos en actos de cine. En el capítulo significativamente titulado Candorosa Cámara de La máquina de visión, Virilio recuerda que los fotógrafos surgidos del documentalismo pueden hacer perder las guerras y que por eso los militares los apartaron de los campos de batalla tras la experiencia de Vietnam (Virilio, 1998: 74); pero de sus reflexiones también se deduce que todo es inútil si ya vivimos sometidos a un universo de pantallas que parece regir 
nuestra relación con lo real. Ahora, las noticias que dan cuenta de un conflicto armado de singular virulencia incorporan imágenes captadas sobre el terreno por los propios participantes en los hechos. Otra vez fuera de control. Lo explicó bien Angel Quintana, quien utiliza el ejemplo de las primaveras árabes: "Las imágenes domésticas rodadas en directo desde el centro de los conflictos han puesto en tela de juicio el papel de los corresponsales de las grandes cadenas internacionales de televisión” (Quintana, 2011:176).

\section{Análisis III. La atracción del horror}

Las imágenes de los conflictos contemporáneos que circulan libremente por la red nos sitúan entre el deseo de ver y el deseo de conocer. En primer lugar, habría que abordar la atracción de aquello que, habitualmente, está ausente de nuestra cotidianidad: la experiencia de la guerra. La creación literaria y la filosófica se han ocupado de explicar eso que podríamos denominar "la atracción del abismo". Tal vez la autoridad de Kant nos sea útil aquí, concretamente cuando afirma: "Hasta los vicios y los crímenes morales conllevan muchas veces algunos de los trazos de lo sublime y de lo bello. Por lo menos así aparecen a nuestro sentimiento sensible, sin ser examinados por la razón" (Kant, 2008:38). En efecto, el filósofo alemán nos aporta ciertas claves con las cuales tratar de entender aquella atracción cuando señala que una venganza manifiesta y valiente, después de una ofensa, encierra algo grandioso y, por ilícita que pueda ser, su narración conmueve a la vez con horror y complacencia. En la senda abierta por Kant, el filósofo español del siglo XX, Eugenio Trías, también se esfuerza por articular un razonamiento lógico que explique esta atracción por el horror: "El sentimiento de lo sublime se alumbra, pues, en plena ambigüedad y ambivalencia entre dolor y placer. El objeto que lo remueve debería, en teoría, despertar dolor en el sujeto. Es un objeto que, de aproximarse a él, el individuo que lo aprehende quedaría destruido o en trance de destrucción" (Trías, 2006:37). Añade Trías, a continuación, que, para poder ser gozado, dicho objeto debe ser contemplado a distancia. Este concepto, el de distancia, nos parece fundamental a la hora de abordar cualquier fenómeno de la comunicación audiovisual, y muy especialmente tratándose de vídeos que nos repelen y atraen al unísono. La distancia debe entenderse, por tanto, en el sentido de exclusión de la corporeidad de la materia significante exhibida a los ojos del espectador, lo que nos sitúa en el núcleo de la idea de espectáculo, siguiendo así el camino marcado por el célebre ensayo de Guy Debord.

Introducir aquí el concepto de distancia nos conduce también, irremediablemente, a hablar de una distancia emocional y a preguntarnos si se activa en el espectador algún tipo de empatía o bien, por el contrario, impera la indiferencia. A la empatía ya nos hemos referido al tratar la cuestión de la transparencia a través de las consideraciones de Baudrillard. No olvidemos, en todo caso, el objetivo último que perseguimos aquí, y que la mayor o menor distancia emocional será un factor esencial en el análisis que se haga del grado de conocimiento que estos registros audiovisuales proporcionan respecto de los hechos mostrados. Sobre este particular, Susan Sontag se ha preguntado si ante las imágenes de la guerra y de la violencia podemos mantener la distancia, si somos capaces de hacer frente a la indiferencia, si aún es posible conmoverse ante la sobreabundancia de vídeos de este tipo. Afirma, a su vez, en otra interesante manifestación de la noción de distancia, que la única experiencia que tenemos de la guerra nos viene dada por el impacto de estas imágenes (Sontag, 2003:49). 
En consecuencia, con la participación decisiva del aspecto emocional y aunque éste pueda derivar en una forma de indiferencia o, directamente, en una ausencia de empatía, habrá que preguntarse finalmente qué comunican estos vídeos respecto de la realidad que muestran, cómo se sitúa ante ella el espectador y, en suma qué conocimiento adquiere. Como ya hemos estudiado, el punto de vista subjetivo que organiza lo real mostrado favorece un efecto de inmersión, una participación por delegación de la cual puede deducirse que da lugar a una modalidad singular de conocimiento empírico, una suerte de experiencia vicaria que encontramos, también, en ciertos discursos audiovisuales de referencia hoy en día, como la publicidad y los videojuegos. Como es sabido, en ellos se busca incidir precisamente, en mayor o menor grado, en la creación de sensaciones, la recreación de experiencias o la explotación de la emotividad. Lo que sin duda parece que no se pretenda es el distanciamiento reflexivo, la comprensión lógica o el pensamiento reposado.

\section{Conclusión. Experiencia mediada y conocimiento}

El análisis de estas piezas audiovisuales fluctúa, por tanto, en torno a ciertos dualismos, como distancia/inmersión, emotividad/indiferencia, experiencia/reflexión o transparencia/opacidad. Añadamos a ello que, recordemos, nos ofrecen un estadio muy primario de construcción discursiva: un registro de acciones que prácticamente se limita a acompañar el movimiento desde el punto de vista de un sujeto implicado en dichas acciones y el respeto por el sonido ambiente. Esto nos permite su abordaje como material en bruto, como aquella materia prima utilizada en una posterior e hipotética elaboración informativa, como así lo demuestra su inserción en determinadas noticias televisivas. Sobre estas bases, la autoridad de Kant puede ofrecer, de nuevo, algunas claves de interés acerca de la relación entre experiencia y conocimiento. El visionado de estas piezas nos conduciría hasta la siguiente formulación del pensador alemán: la materia del conocimiento procede de la experiencia y la forma de conocimiento procede del pensamiento. Dicho con sus propias palabras: "La experiencia es, sin ninguna duda, el primer producto surgido de nuestro entendimiento al elaborar éste la materia bruta de las impresiones sensibles" (Kant, 2005:41). Recordemos, al respecto, que su teoría epistemológica se asienta en la consideración de la sensibilidad y el entendimiento, que quizá tengan una raíz común, como los dos troncos del conocimiento, que por la primera se nos dan los objetos y por la segunda los pensamos.

Los vídeos comentados aquí habría que situarlos, entonces, en aquel primer nivel, el de la materia y la experiencia, allí donde se lleva a cabo la apelación a una emotividad previa a la articulación de un razonamiento argumentado sobre las raíces, las motivaciones o las consecuencias de los conflictos en los que cabe inscribir las acciones mostradas. Impactos perceptivos y emociones fuertes se alían para proceder a un vaciado del relato en tanto que construcción coherente y otorgadora de sentido. Lipovetsky y Serroy aluden a esto mismo cuando afirman que en la cultura mosaico de la pantalla, del estímulo audiovisual y de la diversión permanente, se destruye la disciplina del sentido en beneficio de la indeterminación asumida y de la simpatía emocional (Lipovetsky y Serroy, 2009: 80).

Refuerza esta consideración de relato frustrado en su desarrollo natural la mínima intervención sobre estos materiales audiovisuales, la escasa o nula elaboración que 
abandona las imágenes a su libre capacidad de generar significados, sin más control por parte de una instancia enunciadora que el inmersivo punto de vista subjetivo. Se evita así conducir al sujeto-espectador en una dirección de lectura determinada, sin una pauta clara que le ayude a interpretar aquello que está viendo.

Lo que aquí se ofrece es una vivencia por delegación de hechos excitantes que se experimentan desde la seguridad de la pantalla, desde esta mediación mínima que no incorpora un tratamiento de aquello que, al contrario, nos es dado a ver en su radical crudeza. En este sentido, vídeos como estos constituyen, en cierto modo, un simulacro de percepción directa de las acciones, tal que se tratara de un videojuego, con la paradoja de que cuanto más nos introducimos en el interior de los hechos menos sabemos de ellos, haciendo bueno el principio de que sin distanciamiento crítico no es posible el conocimiento verdadero.

\section{Referencias bibliográficas}

Aumont, Jacques y Marie, Michel (1990): Análisis del film. Barcelona, Paidós Comunicación. Benet, Vicente J. (2007): "Del teatro de operaciones a la visión mecánica de la batalla", en Monegal, Antonio: Políticas y (poéticas) de las imágenes de guerra. Barcelona, Paidós Comunicación, 2007, pp. 37-54.

Baudrillard, Jean (1996): El crimen perfecto. Barcelona, Anagrama.

Casetti, Francesco (1989): El film y su espectador. Madrid, Cátedra.

Cruz, Pedro A. (2005): La muerte (in)visible. Verdad, ficción y posficción en la imagen contemporánea. Murcia, Tabularium.

Gardiés, André (1993): Le Récit filmique. Paris, Hachette.

Hoskins, Andrew (2004): "Televisual Wars", in Sinclair, John and Turner, Graeme: Contemporary World Television. London, British Film Institute, pp. 16-20.

Kant, Inmanuel (2005): Crítica de la razón pura. Madrid, Taurus.

Kant, Inmanuel (2008): Observaciones acerca del sentimiento de lo bello y de lo sublime. Madrid, Alianza.

Lipovetsky, Gilles y Serroy, Jean (2009): La pantalla global. Cultura mediática y cine en la era hipermoderna. Barcelona, Anagrama.

Marzano, Michela (2010): La muerte como espectáculo. La difusión de la violencia en Internet y sus implicaciones éticas. Barcelona, Tusquets.

Quintana, Ángel (2011): Después del cine. Imagen y realidad en la era digital. Acantilado, Barcelona

Sontag, Susan (2003): Olhando o sofrimento dos outros. Lisboa, Gótica.

Trías, Eugenio (2006): Lo bello y lo siniestro. Barcelona, Planeta.

Virilio, Paul (1998): La máquina de visión. Madrid, Cátedra.

Zunzunegui, Santos (2009): "Prólogo", en López Gómez, Antía María: Estrategias de la transparencia. Imposturas de la comunicación mediática. Santiago de Compostela, Servicio de Publicación e intercambio científico USC, pp. 7-11.

Fernando Redondo Neira es Profesor Contratado Doctor, en el área de conocimiento Comunicación Audiovisual y Publicidad, de la Facultad de Ciencias de la Comunicación de la Universidad de Santiago de Compostela. 